\title{
Further evidence for the non-clonal population structure of Neisseria gonorrhoeae: extensive genetic diversity within isolates of the same electrophoretic type
}

\author{
Maria O’Rourke and Brian G. Spratt
}

Author for correspondence: Brian G. Spratt. Tel: +44 273 678309. Fax : +44 273678433.

Microbial Genetics Group, School of Biological Sciences, University of Sussex, Falmer, Brighton BN1 9QG, UK

\begin{abstract}
Analysis of data from multilocus enzyme electrophoresis has revealed that Neisseria gonorrhoeae populations are non-clonal. Fifteen percent of 227 isolates of $\boldsymbol{N}$. gonorrhoeae had an identical multilocus genotype (ET1) and were recovered world-wide over a 26 year period. The recovery of isolates of identical multilocus genotype from geographically and temporally unassociated hosts is a common criterion of a clonal population structure. However, in a recombining (non-clonal) population, isolates with the same multilocus genotype can arise by the random association of the most common alleles in the population. Analysis of the variation in two further enzymes, in the restriction patterns obtained from the glutamine synthetase gene, and in the DNA fragments obtained using an arbitrarily primed polymerase chain reaction, was used to show that members of ET1 were almost as variable as randomly selected $\boldsymbol{N}$. gonorrhoeae isolates. Unlike the situation in a strongly clonal species, the 26 ET1 isolates examined were increasingly sub-divided to give 19 distinguishable groups as variation at further loci was examined, and 24 distinguishable groups when auxotypes were also considered. We conclude that, as expected of a non-clonal population, the most commonly encountered $\boldsymbol{N}$. gonorrhoeae multilocus genotype does not define a clone.
\end{abstract}

Keywords: Neisseria gonorrboeae, electrophoretic type, recombination, non-clonal population structure

\section{INTRODUCTION}

Electrophoretic studies of bacterial populations have revealed that most bacterial species are clonal in structure, implying low rates of recombination between chromosomal genes in nature (Musser et al., 1987, 1988; Ochman et al., 1983; Piñero et al., 1988; Denny et al., 1988; Gargallo-Viola, 1989). Clonal structure is characterized by the existence of strong linkage disequilibrium between alleles, and by the repeated recovery of isolates of the same multilocus genotype (or electrophoretic type, ET) from temporally and geographically unassociated hosts (Selander \& Musser, 1990). Isolates that have the same multilocus genotype are considered to be members of the same clone and, as expected, typically exhibit identity in other characters including ribotypes (Eardly et al., 1990;

Abbreviations: AP-PCR, arbitrarily primed polymerase chain reaction; ET, electrophoretic type.
Arthur et al., 1990), RFLP profiles (Denny et al., 1988; Musser $e t$ al., 1988) and metabolic characters (Selander $e t$ al., 1990; Miller \& Hartl, 1986).

Recent studies suggest that the clonal paradigm for bacterial population structures may be an oversimplification, and that in nature, rates of recombination may be highly variable, resulting in population structures that range from strongly clonal to non-clonal (Istock $e t$ al., 1992; Souza et al., 1992; Maynard Smith et al., 1993; O'Rourke \& Stevens, 1993; Vázquez et al., 1993). We have recently shown that the naturally-transformable species Neisseria gonorrboeae has a non-clonal population structure, implying extensive recombination in nature (O’Rourke \& Stevens, 1993; Vázquez et al., 1993). Although the alleles in a population of gonococci isolated from world-wide locations were at, or close to, linkage equilibrium, $35 / 227(15 \%)$ of the isolates were indistinguishable by multilocus enzyme electrophoresis using nine enzymes, and were thus assigned to a single ET 
(ET1) (O'Rourke \& Stevens, 1993). Similarly, eight other ETs contained more than four isolates.

The existence of apparent 'clones' in a non-clonal population is at first sight contradictory. However, in contrast to a clonal population, in which identity of multilocus genotype implies recent common ancestry, in a recombining (non-clonal) population, isolates of identical multilocus genotype can arise by the random association of the most common alleles at each locus. Thus, in a nonclonal population, isolates with the same multilocus genotype are not the result of recent common ancestry, but represent a collection of genetically diverse isolates that, as a result of frequent recombination, possess the same alleles at each of those loci that are examined.

We have suggested that the $N$. gonorrboeae ETs that are represented by multiple isolates do not define clones since the numbers of isolates in these ETs are not significantly different from those expected to arise by assortative recombination, given the observed allele frequencies (Maynard Smith et al., 1993; O'Rourke \& Stevens, 1993). In this paper we establish that the N. gonorrboeae isolates of ET1 are not members of a clone.

\section{METHODS}

Enzyme electrophoresis. Each of the gonococcal strains was grown in GC broth plus supplements and harvested and lysed using the method described previously (O'Rourke \& Stevens, 1993). Lysates were electrophoresed on $11 \%$ (w/v) starch gels and stained for NADH-dependent diaphorase and NADPHdependent diaphorase as described elsewhere (Selander et al., 1986; Chun et al., 1985).

Polymorphisms within the gInA gene. DNA was purified from lysates by RNase A treatment, followed by phenol/chloroform extraction, and ethanol precipitation. The region encoding the glutamine synthetase gene $(g \ln A)$ was amplified by PCR using the oligonucleotide primers ginA-up (5'-GTCGAT'T'TGCG(GATC)TT(TC)AC(GATC)GA-3') and glnA-down (5'GACGGTTTACAG(GATC)CT(AG)TA(AG)TA-3'). These primers correspond to nucleotides $174-193$ and $1547-1527$ in the sequence of the $N$. gonorrboeae gln $A$ gene (GenBank accession number M84117). The PCR was performed for 22 cycles, as described previously (Zhang et al., 1990), using a cycle of $95^{\circ} \mathrm{C}$ for $1 \mathrm{~min}, 55^{\circ} \mathrm{C}$ for $2 \mathrm{~min}$, and $72^{\circ} \mathrm{C}$ for $2 \mathrm{~min}$. The amplified $1.36 \mathrm{~kb} g \ln A$ fragments were purified by Geneclean (Bio101), digested with $H p a I I$, labelled with $\left[\alpha{ }^{32} \mathrm{P}\right] \mathrm{dCTP}$, and electrophoresed on a $6 \%(\mathrm{w} / \mathrm{v})$ non-denaturing polyacrylamide gel as described previously (Zhang et al., 1990).

Arbitrarily primed PCR (AP-PCR). This was performed using the oligonucleotide Pn-2X-1 (5'-AGGACT(TC)TGTTTGGCGTGATAT-3'). Reaction mixtures were prepared in $50 \mu \mathrm{l}$ volumes containing $100 \mathrm{ng}$ genomic DNA, $1 \mu \mathrm{g} \mathrm{Pn}-2 \mathrm{X}-1,2 \mathrm{mM}$ of each dNTP, $3.5 \mathrm{mM}$ magnesium chloride, $1 \%$ (v/v) DMSO, $15 \mathrm{mM}$ ammonium sulphate, $60 \mathrm{mM}$ Tris $/ \mathrm{HCl}, \mathrm{pH} \mathrm{8.5).} \mathrm{Amplification}$ was carried out for 10 cycles of $95^{\circ} \mathrm{C}$ for $1 \mathrm{~min}, 33^{\circ} \mathrm{C}$ for $30 \mathrm{~s}$, and $67^{\circ} \mathrm{C}$ for $2 \mathrm{~min}$, followed by a further 25 cycles of $95^{\circ} \mathrm{C}$ for $1 \mathrm{~min}, 55^{\circ} \mathrm{C}$ for $1 \mathrm{~min}$, and $72^{\circ} \mathrm{C}$ for $2 \mathrm{~min}$. AP-PCR was performed on each strain seven times.

Auxotyping and serotyping. Auxotyping and serotyping were performed as previously described (O'Rourke \& Stevens, 1993). Strains were tested for single or multiple requirements for arginine, hypoxanthine, uracil and proline.

\section{RESULTS}

Isolates with identical multilocus genotypes that are members of a clone can readily be distinguished from those that are due to random associations of common alleles by an examination of variation at further loci. If the isolates of ET1 are members of a clone there should be essentially no variation at other loci, whereas if they are the result of recombination there should be as much variation within ET1 as in a random collection of gonococcal isolates. We therefore analysed electrophoretic variation in two further enzymes, in the restriction fragments from the glutamine synthetase gene $(g \ln A)$, and in the DNA fragments amplified by AP-PCR (Fekete et al., 1992), in 26 isolates of ET1 and in 26 control gonococci representing isolates of 21 different ETs (Table 1).

\section{Variation at the diaphorase loci}

NADH- and NADPH-dependent diaphorase were both polymorphic for three alleles in the strains analysed (Table 1). The NADH-dependent enzyme was not discriminatory, as allele 2 was present in almost all of the 52 isolates (allele frequency 0.92). The NADPH-dependent enzyme was more variable, with each of the three alleles being found in both the ET1 strains and the control strains.

\section{Variation within the $g \ln A$ gene}

The $g \ln A$ gene of both $N$. gonorrhoeae and N. meningitidis has been shown to be highly variable (J. Zhou, N. H. Smith \& B. G. Spratt, unpublished). Four different patterns of $H p a I l$ fragments were obtained from the $g \ln A$ genes of the $52 \mathrm{~N}$. gonorrhoeae isolates (Fig. 1). Each of these patterns was found among both the ET1 strains and the control strains (Table 1).

\section{Variation detected by AP-PCR}

AP-PCR was carried out using a number of oligonucleotides designed for other purposes. Pn-2X-1, corresponding to a sequence within the Streptococcus pneumoniae penicillin-binding protein $2 \mathrm{X}$ gene, gave the largest number of fragments using N. gonorrboeae FA19 chromosomal DNA and was chosen for further work. Since the AP-PCR technique uses a single primer, the intensity of bands may differ in different PCR reactions of the same strain. Hence, the technique was performed on each strain seven times using standard reaction conditions and a standard reaction mixture. The fragments produced using Pn-2X-1 were reproducible since the same pattern of fragments was obtained using DNA prepared from six independent cultures of $N$. gonorrboeae strain 8030 . The same pattern of fragments was obtained from DNA prepared from this isolate following serial subculture each day for $10 \mathrm{~d}$. A similar stability of fragment pattern was found for a second isolate (4513) following 10 serial subcultures. Thirteen different AP-PCR fragment patterns 
Table 1. Variation among 26 isolates of $N$. gonorrhoeae ET 1 and 26 isolates of varied ET

\begin{tabular}{|c|c|c|c|c|c|c|c|c|c|}
\hline \multirow[t]{2}{*}{ Strain } & \multirow[t]{2}{*}{ Location } & \multirow[t]{2}{*}{ Year } & \multirow[t]{2}{*}{ ET $†$} & \multirow{2}{*}{$\underset{\substack{g \ln A \\
\text { pattern }}}{\text { fingrint }}$} & \multicolumn{2}{|c|}{$\begin{array}{l}\text { Diaphorase } \\
\text { allele }\end{array}$} & \multirow[t]{2}{*}{ AP-PCR } & \multirow[t]{2}{*}{ Serovar } & \multirow[t]{2}{*}{$\begin{array}{l}\text { Auxo- } \\
\text { type }\end{array}$} \\
\hline & & & & & NAD & ADPH & & & \\
\hline Medan 11 & Indonesia & 1983 & 1 & 4 & 2 & 2 & 7 & $1 \mathrm{~A}-4$ & NR \\
\hline Medan 21 & Indonesia & 1983 & 1 & 4 & 2 & 2 & 7 & 1B-13 & $\mathrm{PA}^{-}$ \\
\hline A9446/88 & Norway & 1988 & 1 & 4 & 2 & 2 & 7 & - & $\mathrm{A}^{-}$ \\
\hline$* J 326 \mathrm{~B}$ & Jamaica & - & 1 & 1 & 2 & 2 & 1 & 1B-3 & NR \\
\hline *3551/87 & Scotland & 1987 & 1 & 1 & 2 & 2 & 1 & $1 \mathrm{~B}-3$ & NR \\
\hline *SB2962 & Thailand & 1988 & 1 & 1 & 2 & 2 & 1 & 1B-6 & NR \\
\hline J411B-2 & Jamaica & - & 1 & 1 & 2 & 2 & 1 & $1 \mathrm{~A}-8$ & $\mathrm{PAU}^{-}$ \\
\hline Medan 56 & Indonesia & 1983 & 1 & 1 & 2 & 1 & 1 & $1 \mathrm{~B}-6$ & $\mathrm{P}^{-}$ \\
\hline 5615 & Ireland & 1986 & 1 & 1 & 2 & 1 & 1 & 1B-3 & NR \\
\hline 56567 & Denmark & 1963 & 1 & 1 & 2 & 2 & 7 & 1B-3 & NR \\
\hline $\mathrm{J} 317 \mathrm{~B}$ & Jamaica & - & 1 & 1 & 2 & 2 & 7 & - & $\mathrm{P}^{-}$ \\
\hline Medan 26 & Indonesia & 1983 & 1 & 3 & 2 & 2 & 7 & - & $\mathrm{P}^{-}$ \\
\hline Medan 60 & Indonesia & 1983 & 1 & 1 & 2 & 2 & 6 & $1 \mathrm{~A}-1$ & NR \\
\hline 8030 & Ireland & 1984 & 1 & 1 & 1 & 2 & 7 & 1B-16 & NR \\
\hline 5188 & Ireland & 1985 & 1 & 1 & 2 & 1 & 7 & 1B-3 & $\mathrm{A}^{-}$ \\
\hline 5936 & Ireland & 1985 & 1 & 1 & 2 & 2 & 8 & $1 \mathrm{~A}-7$ & $\mathrm{P}^{-}$ \\
\hline 6 & Ireland & 1988 & 1 & 1 & 2 & 1 & 8 & - & NR \\
\hline 4513 & Ireland & - & 1 & 2 & 2 & 2 & 6 & $1 \mathrm{~A}-5$ & NR \\
\hline SB3270 & Thailand & 1988 & 1 & 1 & 2 & 3 & 6 & $1 \mathrm{~B}-7$ & $\mathrm{P}^{-}$ \\
\hline LDJ 164 & USA & 1989 & 1 & 4 & 2 & 1 & 7 & 1B-7 & $\mathrm{PH}^{-}$ \\
\hline 30991 & USA & 1989 & 1 & 4 & 2 & 2 & 12 & $1 \mathrm{~B}-18$ & NR \\
\hline 36151 & USA & 1989 & 1 & 1 & 2 & 2 & 13 & - & NR \\
\hline 31423 & Denmark & 1963 & 1 & 3 & 2 & 1 & 7 & $1 \mathrm{~A}-1$ & $\mathrm{p}^{-}$ \\
\hline $34083 / 87$ & Scotland & 1987 & 1 & 2 & 2 & 2 & 12 & 1B-3 & $\mathrm{P}^{-}$ \\
\hline Godhab 10 & Greenland & 1986 & 1 & 1 & 2 & 1 & 10 & $1 \mathrm{~A}-14$ & $\mathrm{P}^{-}$ \\
\hline A9972/88 & Norway & 1988 & 1 & 4 & 2 & 2 & 1 & $1 \mathrm{~B}-3$ & $\mathrm{AHU}^{-}$ \\
\hline $9 / 86$ & Botswana & 1986 & 82 & 4 & 2 & 2 & 1 & - & NR \\
\hline 2162 & Ireland & 1987 & 3 & 4 & 2 & 2 & 1 & $1 \mathrm{~B}-3$ & $\mathrm{P}^{-}$ \\
\hline $5 / 86$ & Botswana & 1986 & 3 & 2 & 2 & 2 & 1 & 1B-24 & $\mathrm{P}^{-}$ \\
\hline $34732 / 87$ & Scotland & 1987 & 78 & 2 & 2 & 2 & 1 & $1 \mathrm{~A}-4$ & $\mathrm{P}^{-}$ \\
\hline 56917 & Denmark & 1963 & 51 & 2 & 2 & 2 & 1 & 1B-1 & $\mathrm{A}^{-}$ \\
\hline 8 & Ireland & 1988 & 6 & 1 & 1 & 2 & 6 & $1 \mathrm{~B}-2$ & NR \\
\hline HNL890102 & USA & 1989 & 6 & 1 & 2 & 3 & 10 & $1 \mathrm{~B}-11$ & $\mathrm{PH}^{-}$ \\
\hline $16328 / 87$ & Scotland & 1987 & 33 & 3 & 2 & 1 & 7 & $1 \mathrm{~A}-4$ & NR \\
\hline 30995 & USA & 1989 & 33 & 3 & 2 & 2 & 9 & 1B-3 & $\mathrm{P}^{-}$ \\
\hline Medan 32 & Indonesia & 1983 & 69 & 4 & 2 & 3 & 7 & $1 A-6$ & $\mathrm{P}^{-}$ \\
\hline Medan 63 & Indonesia & 1983 & 69 & 1 & 2 & 1 & 8 & - & NR \\
\hline SB3327 & Thailand & 1988 & 69 & 1 & 2 & 2 & 7 & - & NR \\
\hline 5465 & Ireland & 1986 & 42 & 1 & 1 & 2 & 1 & - & $\mathrm{A}^{-}$ \\
\hline $37178 / 87$ & Scotland & 1987 & 27 & 1 & 2 & 2 & 3 & $1 \mathrm{~B}-14$ & NR \\
\hline 57524 & Denmark & 1963 & 22 & 4 & 2 & 2 & 11 & - & NR \\
\hline 3081 & Dakar & 1982 & 16 & 2 & 2 & 1 & 1 & $1 \mathrm{~B}-4$ & $\mathrm{P}^{-}$ \\
\hline 3084 & Dakar & 1982 & 36 & 1 & 2 & 2 & 4 & - & NR \\
\hline DA 13 & Dakar & 1982 & 40 & 1 & 2 & 2 & 2 & - & NR \\
\hline Godhab 25 & Greenland & 1987 & 31 & 1 & 2 & 1 & 7 & $1 \mathrm{~B}-4$ & $\mathrm{P}^{-}$ \\
\hline $12 / 86$ & Botswana & 1986 & 79 & 1 & 3 & 1 & 1 & 1B-1 & NR \\
\hline $19 / 86$ & Botswana & 1986 & 74 & 3 & 2 & 1 & 5 & $1 \mathrm{~B}-5$ & $\mathrm{PH}^{-}$ \\
\hline SB2629 & Thailand & 1988 & 8 & 1 & 2 & 2 & 10 & $1 \mathrm{~B}-7$ & NR \\
\hline $\mathrm{J} 140 \mathrm{~A}$ & Jamaica & - & 59 & 1 & 2 & 3 & 2 & - & NR \\
\hline $\mathrm{J} 319 \mathrm{~A}$ & Jamaica & - & 14 & 1 & 2 & 3 & 1 & - & - \\
\hline JKD170 & Australia & - & 4 & 1 & 2 & 2 & 1 & $1 \mathrm{~B}-3$ & NR \\
\hline HNL890105 & USA & 1989 & 56 & 3 & 2 & 1 & 1 & $1 \mathrm{~B}-16$ & $\mathrm{PAU}^{-}$ \\
\hline
\end{tabular}

* These three isolates are indistinguishable, except by serovar (see text).

†ETs are as designated previously (O’Rourke \& Stevens, 1993).

$\ddagger$ Requirements for arginine $\left(\mathrm{A}^{-}\right)$, proline $\left(\mathrm{P}^{-}\right)$, proline + arginine $\left(\mathrm{PA}^{-}\right)$, proline + arginine + uracil $\left(\mathrm{PAl}^{-}\right)$, proline + hypoxanthine $\left(\mathrm{PH}^{-}\right)$, arginine + hypoxanthine + uracil $\left(\mathrm{AHU}^{-}\right) . \mathrm{NR}$, no requirements. 


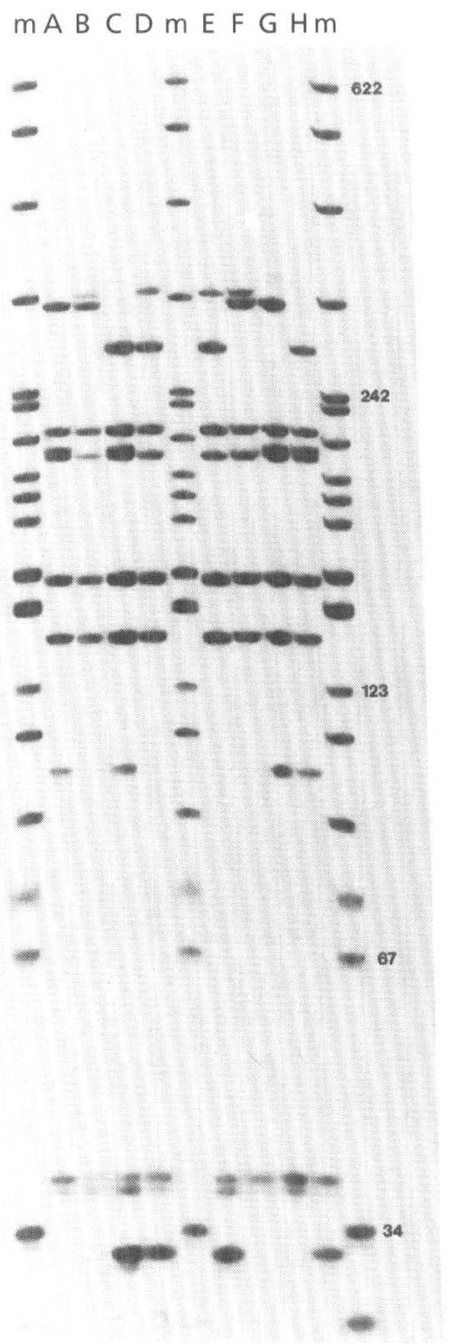

Fig. 1. Hpall fingerprints of the ginA genes of $N$. gonorrhoeae. The ${ }^{32} \mathrm{p}$-labelled Hpall fragments from the $g \ln A$ genes of gonococci were fractionated on a $6 \%(\mathrm{w} / \mathrm{v})$ polyacrylamide gel and autoradiographed as described in the text. Lanes $\mathrm{A}-\mathrm{H}$ correspond to fingerprints of the $N$. gonorrhoeae strains 4513 (2), 31423 (3), 5936 (1), 30991 (4), 2162 (4), 30995 (3), 3081 (2) and J140A (1) respectively; the numbers in parentheses correspond to fingerprint alleles listed in Table 1. Lanes marked m contain size markers (pBR322 digested with Hpall), and the sizes of some of the fragments (in bp) are shown to the right of lane $\mathrm{H}$. The sizes of the visible Hpall fragments of pBR322 are $622,527,404,309,242,238,217,201,190,180,160,147,123$, $110,90,76,67,34$ and 26 bp.

were found among the 52 isolates (Fig. 2). Extensive variation was found among both the ET1 isolates and the control isolates (Table 1).

\section{Variation within ET1 isolates and non-ET1 isolates}

Examination of the variation in the 26 ET1 isolates using the two diaphorase enzymes, $g \ln A$ fingerprinting and APPCR resulted in the splitting of these previously indistinguishable isolates into 19 groups. If the variation in auxotype was also included, the ET1 strains were divided

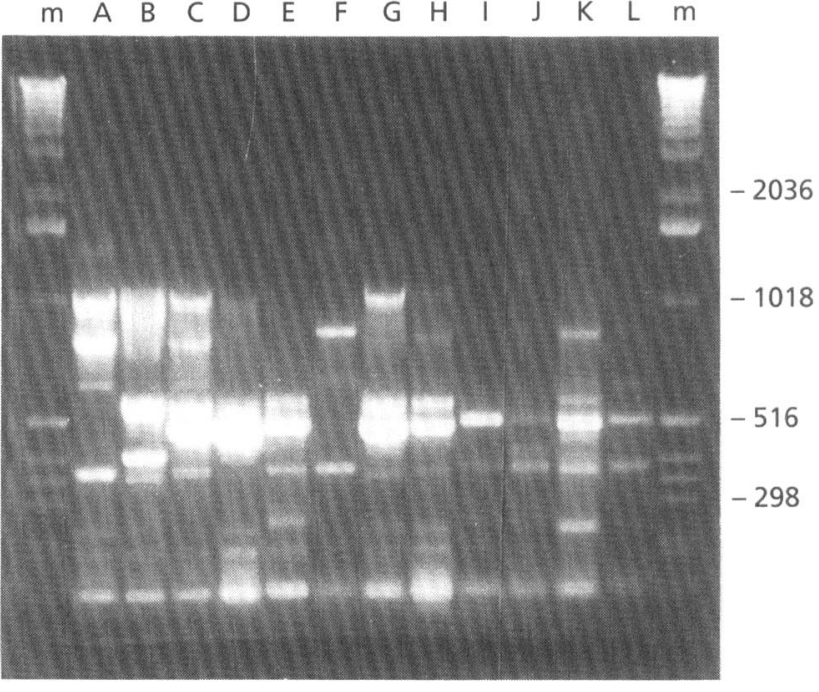

Fig. 2. Electrophoretic analysis of AP-PCR patterns of 12 different $N$. gonorrhoeae strains amplified by primer Pn-2X-1. Patterns depicted in lanes A-L correspond to $\mathrm{N}$. gonorrhoeae strains Medan 32, 36151, 34083/87, SB2629, 5936, 30995, Godhab 10, 30991, 8, 3084, 5615 and 57524 respectively. Lanes A-L correspond to AP-PCR types $7,13,12,10,8,9,10,12,6,4,1$ and 11 respectively. Lanes marked $m$ contain size markers ( $1 \mathrm{~kb}$ DNA ladder) and the sizes of some of the fragments are shown (in bp) to the right of lane L. Three AP-PCR types are not depicted: type 2 consists of a single 370 bp fragment, type 3 resembles type 8 with an additional $750 \mathrm{bp}$ fragment, and type 5 consists of three fragments of 370,390 and $650 \mathrm{bp}$.

further to give 24 groups; and when serovars were considered, only a single pair of isolates were identical. The 26 control gonococci included three isolates from ET69, and two isolates from ETs 3, 6 and 33. Examination of the additional loci showed in each case that these previously indistinguishable isolates could also now be distinguished (Table 1).

If the ET1 isolates are not members of a clone, but are genetically diverse isolates, there should be as much variation within these 26 isolates as in the 26 control isolates. The distribution of alleles, or characters, among ET1 and non-ET1 strains was determined and is illustrated in Fig. 3. The frequency at which the different electrophoretic alleles, $g \ln A$ fingerprints and auxotypes were observed among ET1 strains was almost identical to the frequency at which the characters were observed in non-ET1 strains (Fig. 3). However, particular AP-PCR patterns were encountered at different frequencies in the two groups of strains. Considering the nature of AP-PCR, the number of possible patterns generated could be quite large. To determine whether the differences in the two groups were statistically significant, the variation of this character within the two groups of isolates was estimated as the conditional probability that a pair of isolates drawn randomly from the ET1 group or the control group would match in character. Each isolate was compared with every other isolate in the group and the number of pairs of isolates that matched in character state was recorded. The conditional probability that a pair of 

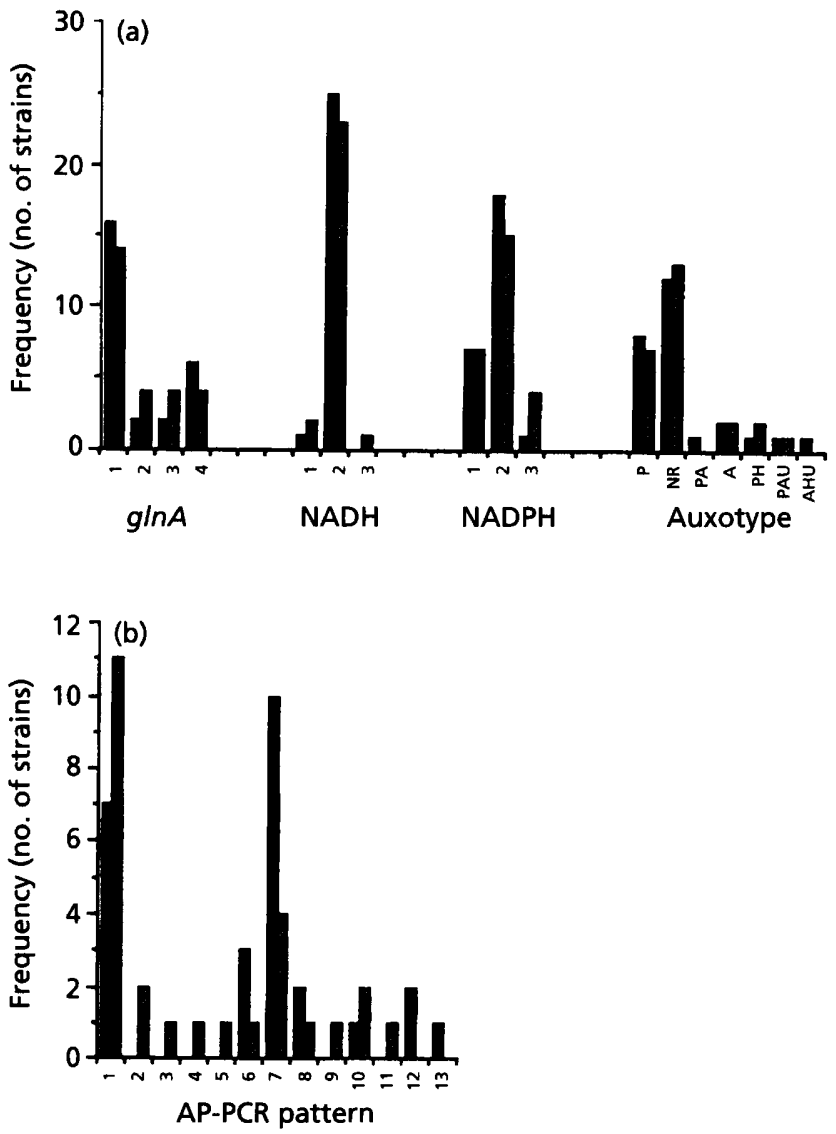

Fig. 3. (a) Distribution of auxotype and $g \ln A, N A D H$ and NADPH alleles among 26 ET 1 ( $\square$ ) and 26 non-ET 1 (שR) isolates. (b) Distribution of AP-PCR patterns among 26 ET $1(\square)$ and 26 non-ET 1 ( correspond to those listed in Table 1.

isolates drawn from the ET1 group would match in character state was $21.8 \%$, while the probability that a pair of isolates from the control group would match in character state was $19 \cdot 4 \%$. The variation in the AP-PCR patterns, and in each of the other characters, was therefore as great or almost as great in the members of ET1 as that in the control group of gonococcal isolates.

\section{DISCUSSION}

O'Rourke \& Stevens (1993) and Vázquez et al. (1993) found no evidence of linkage disequilibrium in two different populations of $N$. gonorrboeae. These results suggest that assortative recombination is frequent in this naturally transformable species and imply that mixed infections are relatively common in gonorrhoea. Even in a non-clonal population, isolates that are indistinguishable will inevitably be recovered from individuals that are epidemiologically linked, but it would be surprising frequently to recover indistinguishable isolates from individuals that are separated both temporally and geographically. The data presented here show that the ET1 isolates, which were indistinguishable by examination of electrophoretic variation at nine enzyme-encoding loci, were highly diverse and are thus not members of a clone. Isolates from four other ETs that included multiple isolates (ETs 3, 6, 33 and 69) were in each case also differentiated by the examination of additional loci, further revealing that gonococcal isolates of shared ET cannot be assumed to be members of a clone. The analysis of relatively few loci, and the presence of predominant alleles at most of the loci studied by O'Rourke \& Stevens (1993), probably accounts for the occurrence of several ETs that were represented by multiple isolates.

Three of the 26 ET1 isolates, recovered at different times in Jamaica, Scotland and Thailand (and indicated by an asterisk in Table 1), could still not be distinguished even when the variation in diaphorase, $g \ln A$ fingerprints, APPCR and auxotype were considered (serovars were not considered as they are subject to convergence and rapid mutational change and are thus unsuitable characters for epidemiological studies). Although these isolates appear to be identical, there is little reason to believe that this is the case, since they possessed the most common alleles at the two diaphorase loci, and the commonest $g \ln A$ fingerprint, AP-PCR pattern and auxotype. By chance, 1.5 isolates with this pattern of variation would be expected among the 26 ET1 strains, based on the frequencies of these alleles/patterns in the 52 gonococci that we examined.

The evidence from multilocus enzyme electrophoresis of frequent recombination (linkage equilibrium), and the diversity within strains of a shared ET, suggest that the epidemiology of gonorrhoea is problematic. Epidemiological conclusions based on studies using the nine enzymes examined by O'Rourke \& Stevens (1993) would clearly be highly misleading, as this method groups diverse isolates into the same ET. A similar criticism applies to other methods of distinguishing gonococcal isolates that depend on small numbers of characters. The non-clonal nature of gonococcal populations implies that isolates recovered in one decade are distinct from those obtained in another decade, and negates attempts to study the long-term epidemiology of gonorrhoea. Fortunately, most studies on the epidemiology of gonorrhoea are concerned with the transmission of the disease on a very restricted geographical and temporal scale. Presumably, the rates of recombination, and the frequency of mixed infections, are not so high that they invalidate the epidemiological conclusions reached within this restricted setting. Further detailed studies of a local population of $N$. gonorrboeae, which includes epidemiologically related strains, would be beneficial and could provide a better insight into the frequency of mixed infections and the extent of recombination in nature.

\section{REFERENCES}

Arthur, M., Arbeit, R. D., Cheung, K., Beltran, P., Crowe, H., Steinbach, S., Campanelli, C., Wilson, R. A., Selander, R. K. \& Goldstein, R. (1990). Restriction fragment length polymorphisms among uropathogenic Escherichia coli isolates: pap-related sequences compared with rrn operons. Infect Immun 58, 471-479. 
Chun, P. K., Sensabaugh, G. F. \& Vedros, N. A. (1985). Genetic relationships among Neisseria species assessed by comparative enzyme electrophoresis. J Gen Microbiol 131, 3105-3115.

Denny, T. P., Gilmour, M. N. \& Selander, R. K. (1988). Genetic diversity and relationships of two pathovars of Pseudomonas syringae. $J$ Gen Microbiol 134, 1949-1960.

Eardly, B. D., Materon, L. A., Smith, N. H., Johnson, D. A., Rumbaugh, M. D. \& Selander, R. K. (1990). Genetic structure of natural populations of the nitrogen-fixing bacterium Rbizobium meliloti. Appl Environ Microbiol 56, 187-194.

Fekete, A., Bantle, J. A., Halling, S. M. \& Stich, R. W. (1992). Amplification fragment length polymorphism in Brucella strains by use of polymerase chain reaction with arbitrary primers. $J$ Bacteriol 174, 7778-7783.

Gargallo-Viola, D. (1989). Enzyme polymorphism, prodigiosin production and plasmid fingerprints in clinical and naturally occurring plasmids of Serratia marcesens. J Clin Microbiol 27, 860-868.

Istock, C. A., Duncan, K. E., Ferguson, N. \& Zhou, X. (1992). Sexuality in a natural population of bacteria-Bacillus subtilis challenges the clonal paradigm. Mol Ecol 1, 195-203.

Maynard Smith, J., Smith, N. H., O'Rourke, M. \& Spratt, B. G. (1993). How clonal are bacteria? Proc Natl Acad Sci USA 90, 4384-4388.

Miller, R. D. \& Hartl, D. L. (1986). Biotyping confirms a nearly clonal population structure in Escherichia coli. Evolution 40, 1-12.

Musser, J. M., Bemis, D. A., Ishikawa, H. \& Selander, R. K. (1987). Clonal diversity and host distribution in Bordetella bronchiseptica. J Bacteriol 169, 2793-2803.

Musser, J. M., Kroll, J. S., Moxon, E. R. \& Selander, R. K. (1988). Clonal population structure of encapsulated Haemopbilus infuenzae. Infect Immun 56, 1837-1845.

Ochman, H., Whittam, T. S., Caugant, D. A. \& Selander, R. K. (1983). Enzyme polymorphism and genetic population structure in Escherichia coli and Shigella. J Gen Microbiol 129, 2715-2726.
O'Rourke, M. \& Stevens, E. (1993). Genetic structure of Neisseria gonorrboeae populations: a non-clonal pathogen. J Gen Microbiol 139, 2603-2611.

Piñero, D., Martinez, E. \& Selander, R. K. (1988). Genetic diversity and relationships among isolates of Rhizobium leguminosarum biovar. phaseoli. Appl Environ Microbiol 54, 2825-2832.

Selander, R. K. \& Musser, J. M. (1990). Population genetics of bacterial pathogenesis. In Molecular Basis of Bacterial Pathogenesis, pp. 11-36. Edited by B. H. Iglewski \& V. L. Clark. Orlando: Academic Press.

Selander, R. K., Caugant, D. A., Ochman, H., Musser, J. M., Gilmour, M. N. \& Whittam, T. S. (1986). Methods of multilocus enzyme electrophoresis for bacterial population genetics and systematics. Appl Environ Microbiol 51, 873-884.

Selander, R. K., Beltran, P., Smith, N. H., Barker, R. M., Crichton, P. B., Old, D. C., Musser, J. M. \& Whittam, T. S. (1990). Genetic population structure, clonal phylogeny and pathogenicity of Salmonella paratyphi B. Infect Immun 58, 2262-2275.

Souza, V., Nguyen, T. T., Hudson, R. R., Piñero, D. \& Lenski, R. E. (1992). Hierarchical analysis of linkage disequilibrium in Rbizobium populations: evidence for sex? Proc Natl Acad Sci USA 89, 8389-8393.

Vázquez, J. A., de la Fuente, L., Berron, S., O'Rourke, M., Smith, N. H., Zhou, J. \& Spratt, B. G. (1993). Ecological separation and genetic isolation of Neisseria gonorrhoeae and Neisseria meningitidis. Curr Biol 3, 567-572.

Zhang, Q.-Y., Jones, D. M., Saez Nieto, J. A., Perez Trallero, E. \& Spratt, B. G. (1990). Genetic diversity of penicillin binding protein 2 genes of penicillin resistant strains of Neisseria meningitidis revealed by fingerprinting of amplified DNA. Antimicrob Agents Chemother 34, 1523-1528.

Received 5 November 1993; revised 6 February 1994; accepted 9 February 1994. 